\title{
GŁÓWNE TENDENCJE ROZWOJOWE REPERTUARU WYDAWNICZEGO NA ŚLĄSKU W OKRESIE RENESANSU
}

Repertuar wydawniczy staje się dziś coraz częściej przedmiotem badań. Ściśle, przynajmniej przez większość dziejów, powiązany z zainteresowaniami czytelniczymi ${ }^{1}$, badany na odpowiednio dużym terenie, rzuca światło na kulturę umysłową spoleczeństwa, ale i badania lokalne mają swoje znaczenie. Produkcja drukarń, zwłaszcza w swej mniej ambitnej części, rozchodziła się przede wszystkim w bliskim otoczeniu i określa do pewnego stopnia lekturę nie odległych pod względem geograficznym kręgów ludności. Prezentowane rozważania nad repertuarem wydawniczym terenu Sląska doby renesansu, nie roszczące sobie pretensji do wyczerpania tematu, oparte są przede wszystkim na publikowanych przez Martę Burbiankę zestawach druków poszczególnych oficyn wrocławskich ${ }^{2}$ oraz na zainicjowanej również przez Martę Burbiankę kartotece starych druków śląskich, przechowywanej obecnie w Oddziale Starych Druków Biblioteki Uniwersyteckiej we Wrocławiu. Dla czasów wcześniejszych nie bez znaczenia były prace Bronisława Kocowskiego ${ }^{3}$. W szeregu przypadków zapoznano się $z$ autopsji z produktami poszczególnych drukarń.

Drukarstwo na Śląsku zapoczątkowała w 1475 r. działalność Kaspra Elyana we Wroclawiu - jeśli nie brać pod uwagę drukarza zw. Typographus Leonis I Papae: „Sermones"4. W okresie inkunabutów i z początkiem XVI w. na Śląsku działali jedynie osiedlający się we Wroclawiu drukarze wędrowni. Dopiero ok. r. 1520 sytuacja zaczęła się zmieniać. Stali drukarze pojawili się we Wrocławiu, do połowy stulecia sztuki drukarskiej próbowano w Legnicy, Oleśnicy, Psiem Polu, były to jednak inicjatywy krótkotrwałe. W drugiej połowie XVI w. działalność drukarska kontynuowana była we Wrocławiu, pojawia się również drukarstwo w Nysie. Drukarstwo nyskie niewiele było dotąd badane, w każdym razie od połowy lat pięćdziesiątych po późne lata osiemdziesiąte funkcjonowała tam oficyna Jana Crucigera, schyłek XVI w. to czas działalności Andrzeja Reinheckela, przez dwa pierwsze dziesięciolecia XVII w. widzimy w Nysie jako typografów Kaspra Sigfrida, Kryspina Scharffenberga, Augustyna Gründera i Jana Schubarta. Pod koniec XVI stulecia pojawiła się znów działalność drukarska w Oleśnicy. Na przełomie XVI i XVII w. do grupy miast, na terenie których rozwijala się produkcja typograficzna dołączyły się Zagań, Brzeg oraz Głogów, z początkiem XVII w. widzimy też działalność drukarni w Bytomiu n.O. Późny renesans był więc na Śląsku okresem ożywionej działalności licznych oficyn drukarskich ${ }^{5}$. 
Przedmiotem naszych rozważań ma być jednak przede wszystkim struktura treściowa produkcji tych drukarń. Tradycje i zwyczaje czasu inkunabułów narzucały produkcję książki religijnej oraz dzieł prawniczych, jako mogących liczyć na pewny zbyt i nie przedstawiających większego ryzyka, ale jedyne początkowo drukarnie śląskie - tłocznie wrocławskie - nie trzymały się w pełni tej reguły. Książka religijna odegrała dominującą rolę $u$ Elyana, byla natomiast skromnie reprezentowana $u$ tloczącego z początkiem XVI w. Konrada Baumgartena, który wyraźnie preferował pisma śląskich humanistów. $U$ żadnego z tych drukarzy nie widzimy dzieł z zakresu prawa cywilnego.

Analizując calą produkcję typograficzną doby renesansu, jaka miała miejsce na Śląsku, stwierdzić przede wszystkim należy, że nadodrzańscy typografowie rezygnowali z publikacji wielkich dzieł o znaczeniu ogólnoeuropejskim. Prowadzone sondaże zdają się wskazywać, że największą grupę stanowiła literatura religijna (łącznie katolicka i protestancka). Poszczególne drukarnie nosiły na ogół zdecydowany charakter wyznaniowy. I tak, kiedy we Wrocławiu w pienwszej połowie XVI w. Adam Dyon i Kasper Lybisch masowo tloczyli druki protestanckie, miasto biskupie Nysa stało się w drugiej połowie XVI stulecia ostoją wydawnictw katolickich. W obrębie tematyki religijnej pod względem liczby tytułów prym dzierżyły publikacje o charakterze luterańskim. Ogólnie rzecz biorąc, widzimy typowa dla środkowej Europy ewolucję: gwaltowny wzrost produkcji książki religijnej w okresie reformacji, sięgającej u Dyona i Lybischa $80 \%$ ogólnej liczby tytułów - była to niemal wyłącznie książka reformacyjna - i lekki spadek w czasach późniejszych. Podobną ewolucję przeżyła na Śląsku książka katolicka $w$ dobie kontrreformacji. $W$ drugiej połowie XVI stulecia drukarnia Crucigera w Nysie wypuszczała około $50 \%$ ksiązek o charakterze religijnym lub $z$ zakresu prawa kościelnego ${ }^{6}$. Potem udział druków religijnych w całości produkcji drukarskiej nieco spada.

Teksty Lutra wydawano głównie we wcześniejszym okresie, tłoczyły je przede wszystkim oficyny Adama Dyona i Kaspra Lybischa we Wrocławiu. Dyon wydat 9 tytułów mistrza $z$ Wittenbergi, Lybisch - 14, były to przeważnie kazania i komentarze do Ewangelii. $W$ drugiej połowie lat dwudziestych popularność Lutra, mierzona obecnością jego pism w śląskim repertuarze wydawniczym, gwałtowanie spadła. Nauka Kalwina, aczkolwiek dość rozpowszechniona w elitarnych kręgach, nie znalazła oddźwięku w lokalnym repertuarze wydawniczym, jej nośnikiem były dzieła sprowadzane z zagranicy. Natomiast publikowano czasem pisma Ulryka Zwinglego, ukazywały się one głównie u Lybischa. Oprócz pism przywódców reformacji, drukarnie śląskie opuszczała rozliczna literatura religijna o charakterze protestanckim pióra pomniejszych autorów. Wymieńmy tu choćby 700 -stronicowe dzieło pastora wroclawskiego Jakuba Beinharta "Hertzenschatz von den fünf Wunden Jesu Christi warumb dieselben an seinen verklärten Leib behalten", wydane w 1593 r. u Mikołaja Sartoriusa w Legnicy?

Niewiele mniej liczne od reformacyjnych, ale w swej zasadniczej masie chronologicznie późniejsze, były druki katolickie. Ośrodek ich produkcji stanowiła Nysa, gdzie tloczono katechizmy ${ }^{8}$, konstytucje synodów wroclawskich ${ }^{9}$, zarządzenia i przywileje biskupów wrocławskich ${ }^{10}$, pisma polemiczne ${ }^{11}$. Wyjątkowo tylko Nysie sekundował Wrocław, gdzie np. Kryspin Scharffenberg opublikowat w r. 1567 
przełożone z Aureliusa Brandoliniusa Lippusa „Passio albo kazanie o męce Pańskiej".

Rzadkim zjawiskiem były teksty biblijne. Potrzeby luteran zaspakajały wysokonakładowe wydania tłumaczeń dokonanych przez Lutra przywożone z Niemiec, głównie z początkiem XVI stulecia, potrzebom katolików służyły edycje biblijne sprowadzane z różnych krajów Zachodu. Wśród nielicznych tekstów biblijnych publikowanych na Śląsku wymieńmy "Das New Testament”, który ukazał się w 1571 r. w Nysie u Jana Crucigera ${ }^{12}$ oraz „Epistolae et Evangeliae, quae dominicis et festis diebus de more catholico in templis recitantur" ${ }^{13}$, wytłoczone $w$ tymże mieście u Kaspra Sigfrida w 1608 r.

Wydawano natomiast często poetyckie parafrazy fragmentów Starego i Nowego Testamentu. Działalność w tym zakresie rozwijali zwłaszcza w Nysie Jan Cruciger i Kasper Sigfrid oraz w Oleśnicy Jan Bössemesser. I tak w zakresie tekstów związanych ze Starym Testamentem ujrzała światło dzienne "Historia de immolando Isaac” pióra Marcina Turnowskiego ${ }^{14}$ oraz „Psalmodiae Davidicae metaphrasis poetica" Kaspra Cunradi ${ }^{15}$. Przechodząc do Nowego Testamentu, wymienić by należało "Tetrastiche Latino-Germanica super Evangelia" wspomnianego Kaspra Cunradi ${ }^{16}$, "Elegia de natali Christi” Walentego Polnera ${ }^{17}$, „Elegia in Natalitia sacro sanctissima" Mikołaja Teubnera ${ }^{18}$, "Historia passionis et mortis Jesu Christi... elegico carmine reddita" Hartmana Schoppera ${ }^{19}$ i wreszcie "Carmen heroicum de resurrectione sacra" Abrahama Horna ${ }^{20}$.

Niewiele było w śląskim repertuarze wydawniczym pism klasyków antycznych, niemniej bukoliki Wergilego ukazały się we Wrocławiu u Kryspina Scharffenberga w 1564 r., a w Nysie u Crucigera w 1573 r.; wybrane ody Horacego we Wrocławiu u Andrzeja Winklera; komedie Terencjusza u Winklera w 1540 r. i u Kryspina Scharffenberga w 1566 r., a w r. 1588 Jan Scharffenberg wydał we Wrockawiu przeróbkę bajek Ezopa.

Rzadko gościły u typografów śląskich teksty ulubieńca renesansowej publiczności - Erazma z Rotterdamu, jednak Scharffenbergowie opublikowali parokrotnie „De civilitate morum puerilium”. Nie znalazły natomiast odzwierciedlenia w nadodrzańskim repertuarze wydawniczym, uznane przez Karola Głombiowskiego za najpopularniejsze, dzieła Erazma: „Adagia”, „Familiaria colloquia”, „De duplici copia verborum ac rerum ${ }^{, 21}$ - popularność ta przejawiała się jednak w lekturze dzieł sprowadzanych z Zachodu.

Często natomiast wydawano utwory pomniejszych poetów renesansowych, nieraz pochodzenia śląskiego. I tak z końcem XVI w. w Legnicy Mikołaj Sartorius publikował utwory poetyckie Andrzeja Calagiusa ${ }^{22}$, z początkiem XVII w. dużą rolę odegrała w tej dziedzinie tłocznia Jana Bössemessera w Oleśnicy, gdzie tłoczono m.in. epigramaty Kaspra Cunradi ${ }^{23}$.

Pewien wpływ na repertuar wydawniczy wywierały wymogi szkolnictwa śląskiego, zwłaszcza wrocławskiego, wyrażone w regulaminie gimnazjum św. Elżbiety we Wrockawiu pióra Piotra Vincentiusa ${ }^{24}$. Wymogom tym tylko w części mogła sprostać produkcja miejscowych drukarń. Produkcja ta w zasadzie była ograniczona do latynistyki. Gramatykę Donata publikowali i Andrzej Winkler i Kryspin Scharffenberg, Donat był jednak zbyt tradycyjny, jak na potrzeby środowiska i po długich 
zabiegach w 1557 r. ukazała się u Kryspina Scharffenberga gramatyka Tomasza Linacra, wreszcie w 1595 r. Reinheckel w Nysie mial wydrukować gramatykę Emanuela Alwareza ${ }^{25}$. Niezależnie od tych publikacji gramatykę Filipa Melanchtona wydał w 1588 r. Jan Scharffenberg.

W zakresie słowników Kryspin Scharffenberg wydał w 1564 r. skromny dykcjonarzyk J. Murmeliusa. Zestaw gramatyk, słowników i podstawowych tekstów wydanych we Wroclawiu nie był jednak wystarczający dla potrzeb szkolnictwa, a tym bardziej dla dojrzałych koneserów kultury antycznej, stąd w kolekcjach śląskich znalazło się wiele pozycji wydanych na Zachodzie.

Ciekawe, choć marginalne zjawisko stanowiły zainteresowania arabistyczne, jakie z początkiem XVII w. przejawiał wroclawianin - Piotr Kirsten, który w latach 1608-1611 wydał we Wrocławiu 9 książek arabistycznych ${ }^{26}$.

Rzadkim gościem były w śląskich oficynach teksty historyczne. Wśród nielicznych przykładów tej tematyki wymienić można wytłoczone w $1565 \mathrm{r}$. u Crucigera *: Nysie Tilmana Bredenbacha „Belli Livonici, quod Magnus Moschoviae Dux anno 1558 contra Livones gessit... historia"27.

Wśród zagadnień politycznych dużą rolę odegrała sprawa turecka, przejawiająca swą obecność w publikacji ulotnych pism powiadamiających o wydarzeniach wojennych, a także w masowym drukowaniu tekstów modlitw, mających ustrzec przed nawałą turecką.

Produkcja dzieł z zakresu prawa była niewielka, jeśli już drukowano, to zarządzenia o charakterze lokalnym ${ }^{28}$.

Zainteresowania medyczne przejawiały się głównie w publikacji druków informujących o sposobach ochrony przed zarazą. Czasem jednak wychodzono poza tę tematykę. Szczególnie często czynił to w Nysie Jan Cruciger, który wydał Jana Schitlera „Ein Hausbüchlein in welchem die Kranckheiten des gantzen Leibes... kürtzlich gehandelt" (1576) oraz, wkraczając w budzącą coraz większe zainteresowanie dziedzinę anatomii: „Brevis descriptio corporis humani discentibus valde utilis" $(1572)^{29}$. Cruciger sięgnął też po teksty Paracelsusa, publikując m.in. „De urinarum ac pulsuum indiciis" $(1566)^{30}$. Zainteresowania medyczne znalazły też odzwierciedlenie w wydanej w 1587 r. u Reinheckela w Nysie publikacji Simona Simoniusa dotyczącej przyczyn zgonu króla polskiego Stefana Batorego ${ }^{31}$.

Astronomia wyjątkowo tylko przyciągała uwagę bibliopoli śląskich. Tak było w przypadku pojawienia się komety, co spowodowało ukazanie się u Jana Bössemessera w Oleśnicy w $1605 \mathrm{r}$. „De significatione et effectibus stellae novae s. cometae" autorstwa Jakuba Günthera ${ }^{32}$. Publikowano natomiast prognostyki, wspomnijmy tu tylko parokrotnie pod różnymi tyłułami wydawane przez Kryspina Scharffenberga we Wrocławiu „Dzienne sprawy...” Kaspra Goskiego.

W drugiej połowie stulecia, kiedy drukarnie śląskie stały się zdolne do masowej produkcji, bardzo dużą rolę odegrały druki okolicznościowe. Wydawano je zazwyczaj z okazji urodzin, zawarcia związku małżeńskiego (te są najliczniejsze), zgonu. Teksty te nosity najczęściej formę poetycką. Dotyczyły przeważnie kręgów mieszczańskich, ale też magnackich i książęcych, sięgając aż po osobę cesarza. Druki ulotne były też nośnikami wiadomości politycznych oraz wieści o wszelkiego rodzaju innych wydarzeniach. U Scharffenbergów we Wrocławiu produkcja tego 
rodzaju stanowiła prawie połowę ogólnej liczby tytułów. Różnorakie funkcje druków okolicznościowych zostały przejęte przez czasopisma dopiero w XIX w.

Tak więc śląska produkcja drukarska, początkowo niewielka i mało zróżnicowana, wzbogaciła się i rozrosła z biegiem czasu, jednak zawsze nadodrzański repertuar wydawniczy miał charakter skromny i lokalny, a bardziej wymagający odbiorcy książek sięgali po edycje zachodnie. Niemniej, drukarstwo śląskie odegrało ważną rolę, dostarczając książki wprawdzie nieefektownej, ale docierającej do szerokich kręgów ludności.

\section{Przypisy}

${ }^{1}$ K. Glombiowski, Problemy historii czytelnictwa, Wroclaw 1966, s. 15-20.

${ }^{2}$ Andrzej Winkler, drukarz wrocławski XVI w. "Roczniki Biblioteczne”, R. 4:1960, s. 413-440; Adam Dyon i Kasper Lybisch, wroclawscy drukarze reformacyjni, tamże, R. 5:1961, s. 89-112; Produkcja typograficzna Scharffenbergów we Wroctawiu, Wroctaw 1968, s. 104-278; Drukamia Konrada Baumgarta we Wroctawiu „Roczniki Biblioteczne”, R. 14:1970, s. 89-93.

${ }^{3}$ Śląskie studia inkunabulistyczne [W:] Z dziejów ksiażki na Ślasku, Wrocław 1953, Prace Wroctawskiego Towarzystwa Naukowego, Seria A, Nr 52; Zarys dziejów drukarstwa na Dolnym Śląsku, "Sobótka", R. 2:1947 [i odb.]

${ }^{4}$ A. Lewicka-Kamińska, Zagadka drukarza kazań papieża Leonal (tzw. Typographus Leonis I Papae: "Sermones") „Roczniki Biblioteczne", R.20:1976, s. 518-524.

${ }^{5}$ B. Kocowski, Zarys dziejów drukarstwa na Dolnym Śląsku, passim; M. Burbianka, Andrzej Winkler, drukarz wroctawski XVI w., s. 363, 369; taże, Adam Dyon i Kasper Lybisch.... s. 67, 73-75, 83; taże, Produkcja typograficzna Scharfenbergów we Wroclawiu, s. 27, 36, 41, 49; taże. Drukamia Konrada Baumgarta we Wroclawiu, s. 63, 81; taże, Z dziejów drukarstwa śląskiego w XVII w. Baumannowie, Wroclaw 1977, s. 11-13, 22, 26-28; F. Kaminsky, Beiträge zur Geschichte des oberschlesischen Buchbinderei-, Buchdruck-, Buchhandels-, Zeitungs u. Bibliothekswesens bis 1815, Oppeln 1927, s. 35; Biblioteka Uniwersytecka we Wrockawiu (dalej: Bibl. Uniw. Wroct.), Oddział Starych Druków: Kartoteka starych druków śląskich.

${ }^{6}$ Obliczeń dotyczących Nysy dokonano na podstawie kartoteki starych druków śląskich w Bibl. Uniw. Wroct., Oddział Starych Druków.

7 Bibl. Uniw. Wrocl., Oddzial Starych Druków, sygn. 300217; A. Mendykowa, Dzieje legnickiej Sartoriany ${ }_{n}$ Roczniki Biblioteczne", R. 7:1963, s. 43.

${ }^{8} \mathrm{~Np}$. Ein christlicher Catechismus und aus beyden heyligen Alte und Newen Testamenten auch allen Wolbewertten beyligen alten Vetern und Concilien sehr wol gegründte Lehr und Underricht, Gedruck zur Neyss, 1570 (Bibl. Uniw. Wroct., Oddział Starych Druków, sygn. 347562).

${ }^{9} \mathrm{~Np}$. Breves diocesanae synodi Vratislaviensis constitutiones, Nissae, Cruciger 1580, tamże, sygn. 440742; Acta et constitutiones Sinodi Diocesanae, quae fuit celebrata Wratislaviae in Insula s. Joannis anno MDXCII mense octobri... Nissae per Andream Reinheckel 1595, tamże, 440026, E.XII.30.

${ }^{10} \mathrm{~Np}$. Landesordnung von... Balthasar Bischoffen zu Breslaw, Neyss, Andreas Reinheckel 1593, tamże sygn. 441715; Landesordnung von Balthasar Bischoffen zu Breslau, Neyss, Augustinus Grūnder 1615 , tamże, sygn. 441713.

${ }^{11}$ Np. Marcin Śmiglecki, Nova monstra novi arianismi..., Nissae, Crispin Scharffenberg 1612, E. XXVIII, 312; Augustyn Sokołowski, Merckzeichen... das die Catholische die rechte unfehlbare Kirche sey..., Neyss, Augustyn Grūnder, 1615, E. XXIX, 5.

${ }^{12}$ Bibl. Uniw. Wroct., Oddzial Starych Druków, sygn. 300294.

13 Tamże, sygn. 301054.

${ }^{14}$ Nyssae 1580, E. XXXI s. 408. 
${ }^{15}$ Olsnae, Praelo Bössemesseriano, Bibl. Uniw. Wroct., Oddzial Starych Druków, sygn. 300848.

${ }^{16}$ Olsnae, Joannes Bössemesser, 1606, tamże, sygn. 302644.

${ }^{17}$ Nissae, Joannes Cruciger, tamże, sygn. 408526.

${ }^{18}$ Olsnae, Joannes Bössemesser, 1605, tamże, sygn. 441235.

${ }^{19}$ Nissae, Joannes Cruciger, 1563, tamże, sygn. 442270.

${ }^{20}$ Olsnae, Typis Bōssemesserianis, 1610, tamże, sygn. 440462.

${ }^{21} \mathrm{~K}$. Głombiowski, O poczytności Erazma z Rotterdamu na Śląsku w dobie odrodzenia „Roczniki Biblioteczne", A.4:1960, s. 14, 20, 21.

${ }^{22}$ A. Mendykowa, op.cit., s. 43.

${ }^{23}$ Epigrammatum centuria I. Ad... Wenceslaum a Zedlitz, 1609, Bibl. Uniw. Wroct., Oddzial Starych Druków, sygn. 300829; Epigrammatum Centuria II. Ad... Nicolaum Rhedingerum, 1610, tamże, sygn. 300830; Epigrammatum centuria III. Ad... Abrahamum a Promnitz, 1610, tamże, sygn. 300831.

${ }^{24}$ M. Burbianka, Produkcja typograficzna Scharffenbergów we Wrocławiu, s. 53.

${ }^{25}$ Gesamtkatalog der Preussischen Bibliotheken III, Berlin 1933, 3, 8400.

${ }^{26}$ K. Migoń, Recepcja książki orientalistycznejna Śląsku do końca XVIII w., Wroclaw 1969, s. 140-144.

${ }^{27}$ Bibl. Uniw. Wroct., Oddział Starych Druków, sygn. 300429.

${ }^{28}$ Za przykład może tu posłużyć druk: Ordnung und Constitution wie es im Waisen Sachen bey der Fürstlichen Stadt Olsse gehalten werden soll, Öls, Johann Bössemesser, tamże, sygn. 409665.

${ }^{29}$ Tamże, sygn. 304029, 304026.

${ }^{30}$ Tamże, sygn. 4 V 27/3 (wg kartoteki starych druków śląskich).

31 Tamże, sygn. 410876.

32 Tamże, sygn. 409644. 